DOI: http://dx.doi.org/10.25181/esai.v12i2.1093

Jurnal Ilmiah ESAI Volume 12, No. 2, Juli 2018

p-ISSN 1978-6034 e-ISSN 2580-4944

The Impact of Adoption of International Financial Reporting Standards (IFRS) on Conservatism of Accounting Information in Companies in Indonesia

\title{
Dampak Adopsi International Financial Reporting Standards (IFRS) Terhadap Konservatisme Informasi Akuntansi pada Perusahaan di Indonesia
}

\author{
Ratna Puji Astuti' ${ }^{1)}$, Agus Kuntoro ${ }^{2)}$ \\ 1,2) Staf Pengajar pada akademi Akuntansi YKPN, Yogyakarta \\ e-mail: ratna_puji_astuti@yahoo.com
}

\begin{abstract}
The objective in this study is to examine empirically changes in the level of conservatism of corporate accounting information in Indonesia as a result of the use of Financial Accounting Standards (IFRS) adopted by IFRS (International Financial Reporting Standards). Conservatism was measured using the Market-to-Book bias component model (Beaver and Ryan, 2000). This study uses the Financial Statement data from 178 companies, 2007 to 2016, listed on the Indonesia Stock Exchange. Using multiple regression models that place accounting conservatism as a dependent variable while IFRS adoption, managerial ownership, institutional ownership, and public ownership as independent variables, this study proves that IFRS adoption does not affect the level of conservatism of accounting information. The size of the firm (size) and the composition of debt (leverage) is a control variable that participates in controlling the model of this study.
\end{abstract}

Keywords: IFRS adoption, conservatism of accounting information.

\section{Pendahuluan}

Penelitian ini bertujuan untuk menyediakan bukti empiris tentang dampak adopsi International Financial Reporting Standards (IFRS) terhadap kualitas pelaporan keuangan, dengan menggunakan proksi konservatisme akuntansi (Basu, 1997; Ball and Shivakumar, 2005), pada perusahaan yang terdaftar di Bursa Efek Indonesia. Adopsi IFRS secara luas oleh negara-negara di dunia, seiring dengan berlakunya regulasi International Accounting Standards (IAS) pada tahun 2002, mendorong perusahaan untuk menjadikan the Conceptual Framework for Financial Reporting 2010 yang disetujui oleh IASB (IFRS Framework), sebagai landasan teoritis bagi penyusunan standar akuntansi lokal masingmasing negara.

Menurut Hung dan Subramanyan (2007), menguji dampak adopsi IAS penting, karena 
DOI: http://dx.doi.org/10.25181/esai.v12i2.1093

adopsi standar internasional mungkin menyebabkan konsekuensi ekonomi secara tidak langsung seperti likuiditas pasar menjadi lebih tinggi atau biaya modal menjadi lebih rendah, namun satu-satunya dampak langsung adopsi IAS adalah perubahan laporan keuangan. Penelitiannya menunjukkan bahwa total aset dan nilai buku ekuitas, serta variabilitas nilai buku dan laba bersih, secara signifikan lebih tinggi dibawah IAS daripada ketika menggunakan standar lokal German Accounting Rules (HGB). Di dalam penelitiannya juga ditemukan bahwa nilai buku (laba bersih) memainkan peran penilaian yang lebih besar (lebih rendah) di bawah IAS daripada HGB. Penyesuaian IAS terhadap nilai buku umumnya bernilai relevan, sedangkan penyesuaian terhadap pendapatan umumnya bernilai tidak relevan. Hal ini memberikan wawasan baru tentang perbedaan antara akuntansi yang berorientasi pada pemangku kepentingan (stakeholder) dan akuntansi yang berorientasi pada pemegang saham (shareholders). Implikasi penerapan laporan keuangan menggunakan IAS yang berorientasi pada pemangku kepentingan merupakan sebuah isu yang sangat penting bagi negara-negara di Eropa.

Mengingat bahwa standar akuntansi secara langsung mempengaruhi kualitas pelaporan (Soderstrom and Sun, 2007), menjadi kebutuhan mendesak untuk memahami dampak atas perubahan laporan keuangan yang disusun berdasarkan IFRS. Tujuan International Accounting Standards Board (IASB) adalah untuk mengembangkan, dalam kepentingan umum, satu standar berkualitas tinggi, standar akuntansi global yang dapat dimengerti dan dapat dilaksanakan yang berkualitas tinggi, transparan, dan informasi yang dapat dibandingkan dalam laporan keuangan dan pelaporan keuangan lainnya untuk membantu pelaku pasar modal dunia dan pengguna pembuat keputusan ekonomi lain.

Dickhaut et. al. (2010) dan Littleton (1994), menyatakan bahwa prinsip konservatisme telah ada sejak abad XV, mendukung risalah Pacioli tentang pembukuan akuntansi. Sterling (1967) menganggap konservatisme akuntansi sebagai prinsip tertua yang telah mempengaruhi praktik akuntansi. Konservatisme selalu diakui sebagai salah satu prinsip terpenting dalam akuntansi. Konservatisme membatasi penilaian yang lebih tingi (overstatement) terhadap aset dan pendapatan bersih. Telah ada konsensus umum antara regulator akuntansi dan pembuat laporan akuntansi bahwa konservatisme adalah karakteristik informasi akuntansi yang menarik dan sangat relevan bagi banyak pengambil keputusan. Kualitas informasi akuntansi yang lebih tinggi akan disertai dengan konservatisme 
yang lebih tinggi dan makin berkurangnya informasi asimetri (Watts, 2003).

Sampai saat ini, kerangka konseptual IASB dan FASB memiliki tempat untuk konservatisme atau 'kehati-hatian' (prudence), dimensi keandalan yang merupakan salah satu dari empat prinsip karakteristik kualitatif dari laporan keuangan (Andre et. al, 2013). Yang mengejutkan banyak pihak, perpaduan baru antara kerangka konseptual IASB dan FASB yang diadopsi pada bulan September 2010, sudah diajukan sejak awal tahun 2000-an, (Bab 1 Tujuan Pelaporan Keuangan dan Bab 2 Karakteristik kualitatif) tidak memasukan konservatisme atau 'kehati-hatian' sebagai sesuatu yang disyaratkan sebagai kualitas pelaporan keuangan (IASB, 2010). IASB menganggap 'faithful representation' sebagai sebuah karakteristik kualitatif fundamental dari informasi keuangan yang menyiratkan fokus pada kelengkapan (completeness), netralitas (neutrality), dan kebebasan dari kesalahan (feedrom of error). Contoh 'netralitas' dibawah IFRS termasuk penggunaan nilai wajar, penurunan nilai (impairment) bukan amortisasi termasuk kemungkinan untuk membalikkan penurunan sebelumnya dan peraturan yang lebih ketat mengenai bagaimana dan kapan harus mengakui provisi. ${ }^{1}$

${ }^{1}$ IAS 37 dikatakan oleh banyak pihak untuk untuk membatasi 'cadangan atau persediaan' yang cukup lazim di Benua Eropa (Walton, 2011).
Namun, seperti telah dijelaskan di atas, bentuk 'kehati-hatian' yang dimaksudkan oleh IASB untuk mengeliminasi pelaporan keuangan dari konservatisme tidak kondisional, bukan konservatisme kondisional (IASB, 2010). Berdasarkan perspektif konseptual, kerangka konseptual IASB dan IFRS mempromosikan konservatisme kondisional dengan membatasi konservatisme tidak kondisional. Namun, sebenarnya tingkat konservatisme kondisional dan tidak kondisional pelaporan keuangan tergantung dari penerapan prinsip tersebut.

Basu (1997) berpendapat, diperlukan verifikasi untuk memperhitungkan akun keuntungan dan kerugian. Akuntan membutuhkan tingkat verifikasi yang lebih tinggi untuk mengenali kabar baik dibandingkan dengan kabar buruk. Basu (1997), konservatisme mendukung dan melindungi kepentingan pemegang saham karena mereka memerlukan informasi yang tepat waktu, terutama bila menyangkut berita buruk, untuk membuat keputusan (Lara dan Mora, 2004). Konservatisme adalah penilaian yang rendah terhadap pendapatan dan aset, yang bertujuan untuk melindungi kreditur (Nobes dan Parker, 2008). Konservatisme akuntansi memainkan peran yang efektif dalam realisasi kesepakatan antara perusahaan dengan berbagai pihak.

Adopsi IFRS, dalam beberapa dekade terakhir, oleh sejumlah besar negara telah

Jurnal Ilmiah Esai Volume 12, No. 2, Juli 2018 
membawa isu konservatisme akuntansi menjadi pusat perhatian bagi profesional dan akademisi dalam bidang akuntansi (Zeghal, 2016). Konservatisme dipandang sebagai kemampuan diferensial laba akuntansi untuk merefleksikan rugi ekonomi dibanding laba ekonomi (Zeghal et al., 2012). Penelitian Masca dan Neag (2014) menunjukkan dampak adopsi IFRS yang diukur dengan konservatisme akuntansi dan tingkat konservatisme negara-negara yang standar lokalnya mengadopsi IFRS menurun, tetapi perusahaan-perusahaan besar justru sekarang menghendaki konservatisme.

Indonesia, sebagai satu negara berkembang tidak ketinggalan dalam mengadopsi IFRS. Adopsi SAK ke IFRS semakin menggema ketika IAI mencanangkan adopsi SAK ke IFRS secara bertahap mulai 1 Januari 2012. Program adopsi yang dimulai secara bertahap dengan penerapan PSAK, ISAK, dan PPSAK sudah dimulai sejak tahun 2008 (DSAK, 2015). Adopsi IFRS ini merupakan salah satu butir kesepakatan pemerintah Indonesia sebagai anggota forum G-20. Seperti yang terjadi di negara-negara lain, masih terdapat perdebatan konseptual dan penelitian penting apakah penerapan IFRS di Indonesia dapat meningkatkan kualitas pelaporan keuangan. Selain itu penelitian terkait dengan dampak adopsi IFRS selama ini berfokus pada perubahan informasi komponen laba untuk tujuan penilaian terhadap pengenalan IFRS (Barth et al., 2008; Daske et al., 2008), namun belum menggambarkan bagaimana kualitas pelaporan keuangan yang disajikan, sehingga diperlukan penelitian lanjutan.

Penelitian ini bertujuan untuk menutup celah penelitian tersebut dengan melakukan penelitian di negara berkembang, yaitu Indonesia tentang dampak adopsi IFRS (International Financial Reporting Standards) terhadap konservatisme informasi akuntansi pada perusahaan di Indonesia. Oleh karena itu, penelitian ini bertujuan untuk menjawab pertanyaan berikut:

\section{RQ1. Apakah terjadi perubahan tingkat konservatisme informasi akuntansi pada perusahaan di Indonesia yang menyajikan} laporan keuangan dengan menggunakan standar akuntansi hasil adopsi dari IFRS?

Berdasarkan bukti empiris, penelitian ini membuktikan apakah terjadi perubahan tingkat konservatisme informasi akuntansi pada perusahaan yang menyajikan laporan keuangan dengan menggunakan standar akuntansi adopsi IFRS. Berdasarkan asumsi bahwa terjadi penurunan tingkat konservatisme bagi negaranegara yang standar lokalnya mengadopsi IFRS (Masca dan Neag, 2014), namun perusahaanperusahaan besar justru sekarang menghendaki konservatisme. Peneliti memprediksi bahwa tingkat konservatisme akuntansi perusahaan- 
perusahaan besar di Indonesia sejalan dengan adopsi IFRS ke dalam Standar Akuntansi Keuangan (SAK). Kontribusi penelitian ini adalah memberikan tambahan bukti empiris terhadap literatur bagi akademisi maupun regulator dalam mengevaluasi dampak serta konsekuensi adopsi IFRS terhadap standar akuntansi yang mereka susun atau kembangkan.

Tujuan penelitian ini adalah untuk menutup beberapa keterbatasan penelitian sebelumnya, yaitu rentang waktu penelitian, pengukuran konservatisme akuntansi dan sampel dipertimbangkan, untuk mendapatkan hasil yang lebih komprehensif dan lebih meyakinkan tentang pengaruh adopsi IFRS terhadap konservatisme akuntansi. Beberapa hal penting yang membedakan penelitian ini dari penelitian sebelumnya. Penelitian ini menggunakan periode waktu yang lebih panjang terutama setelah adopsi IFRS yang memungkinkan analisis yang lebih baik dari konsekuensi penggunaan standar akuntansi. Kedua, penelitian sebelumnya yang membandingkan konteks yang berbeda tidak membedakan efek dari adopsi IFRS dari pengaruh lingkungan institusional yaitu struktur kepemilikan, sebagai faktor yang ikut menentukan konservatisme.

Sistematika penulisan penelitian ini diawali dengan pendahuluan yang menjelaskan motivasi dilakukannya penelitian ini, pemaparan kajian literatur dan pengembangan hipotesis, dilanjutkan dengan metode penelitian, diskusi hasil analisis dan pembahasan, dan diakhiri dengan kesimpulan hasil penelitian.

\section{Kajian Literatur Dan Pengembangan Hipotesis}

\section{Rerangka Teoritis}

\section{International Financial Reporting Standards (IFRS) dan Informasi Akuntansi}

International Financial Reporting Standards (IFRS) merupakan standar akuntansi internasional yang disusun oleh International Accounting Standards Board (IASB), yang pada awal terbentuknya bernama International Accounting Standards Committee (IASC). IASC dibentuk di London, Inggris pada tanggal 29 Juni 1973. Gagasan mengenai pengembangan standar akuntansi global terus bergulir sejak terbentuknya IASC, yang merupakan cikal-bakal dewan penyusun IFRS, dalam $10^{\text {th }}$ World Congress of Accountants di Sydney Australia tahun 1972. Organisasi ini dibentuk dengan tujuan untuk mengembangkan standar akuntansi internasional dan mempromosikan penerapan atas standar tersebut.

Menurut Zeghal dan Mhedhbi (2006), menyatakan bahwa adopsi standar akuntansi internasional selalu menjadi subjek kontroversi dalam literatur akuntansi oleh negara-negara yang berbeda. Terdapat 2 aliran pemikiran yang 
berbeda mengenai hal tersebut. Pendapat pertama mendukung penerapan standar internasional, karena adopsi IFRS cenderung meningkatkan kualitas laporan keuangan. IFRS mengurangi praktik manajemen oportunistik oleh manager, manajemen laba, peluang yang lebih besar untuk pengakuan kerugian dan relevansi nilai pendapatan bersih yang lebih besar (Barth et al., 2008). Penelitian Daske, Leuz, dan Verdi (2008) tentang dampak ekonomi implementasi IFRS di 26 negara mampu meningkatkan likuiditas pasar, mengurangi biaya modal (cost of capital), dan meningkatkan nilai perusahaan. Hal tersebut didukung dengan studi yang dilakukan oleh Barth, et. al. (2008) yang menyimpulkan bahwa perusahaan-perusahaan yang mengadopsi standar akuntansi internasional, kualitas informasi akuntansinya meningkat dibanding periode sebelum adopsi.

Pendapat kedua menyatakan bahwa standar berkualitas tinggi tidak selalu menghasilkan informasi akuntansi berkualitas tinggi. Penelitian Ball et. al. (2003) menunjukkan bahwa IFRS tidak diperlukan untuk menghasilkan informasi yang berkualitas tinggi. Kualitas pelaporan ditentukan oleh faktor-faktor politik dan ekonomi serta lingkungan institusional, bukan hanya oleh aturan tersebut saja, contohnya, beberapa negara telah memperkenalkan contoh mekanisme pengendalian yang efisien atau tata kelola (Chen et. al., 2010). Argumen ini didukung oleh Van Tendeloo dan Vanstraelen (2005), yang dalam penelitian terhadap adopsi sukarela IFRS oleh negara-negara di Jerman, memperoleh bukti dampak positif adopsi standar internasional pada level manajemen laba dan arus kas operasi yang lebih rendah, meskipun dampaknya berkurang ketika perusahaan diaudit oleh salah satu the Big 4/5 auditors. Adopsi IFRS mungkin tidak menghasilkan manfaat yang diperlukan namun hanya menyajikan perubahan akuntansi dengan tanpa memiliki manfaat ekonomi (Mazars, 2006) bahkan justru menurunkan kualitas informasi akuntansi (Janjean dan Stolowy, 2008).

Sejalan dengan adopsi IFRS, entitas harus mengikuti Conceptual Framework for Financial Reporting 2010 yang sudah disetujui oleh IASB (IFRS Framework), sebagai dasar teoritis dari semua standar akuntansi. Berdasarkan rerangka konseptual IFRS sebagai dasar utama untuk mendefinisikan kualitas akuntansi sebagai berikut:

The qualitative characteristics of useful financial reporting identify the types of information are likely to be most useful to users in making decisions about the reporting entity on the basis of information in its financial report. The qualitative characteristics apply equally to financial information in general purpose financial 
DOI: http://dx.doi.org/10.25181/esai.v12i2.1093

reports as well as to financial information provided in other ways. [IFRS Foundation, F

QC1, QC3, hal. A33]

Menurut Chen et. al. (2010), kualitas akuntansi mewakili sejauh mana informasi laporan keuangan mencerminkan situasi ekonomi yang mendasarinya. Platikanova dan Perramon (2012) berpendapat bahwa suatu informasi berkualitas tinggi jika pengguna dapat mengidentifikasi kesamaan dan perbedaan antara dua fenomena ekonomi. IFRS diterapkan untuk menghilangkan eksternalitas informasi yang timbul dari kurangnya komparatif.

Di antara peluang untuk mengukur kualitas pelaporan keuangan, proksi yang paling banyak dipergunakan dalam literatur adalah: kualitas laba, konservatisme akuntansi, dan kualitas akrual. Penman dan Zhang (2002) berpendapat bahwa konservatisme menimbulkan masalah tentang kualitas informasi dan laba akuntansi. Praktik konservatif menciptakan "cadangan tersembunyi", karena memperkirakan aset dengan nilai yang rendah dan liabilitas dengan nilai yang tinggi. Konservatisme dapat menyebabkan kurangnya komparabilitas, karena kurangnya standar untuk pelaksanaannya, sehingga menyebabkan informasi keuangan menjadi tidak relevan Hendriksen dan Breda (1999).

\section{Konservatisme Conservatism)}

Akuntansi (Accounting

Menurut FASB (Statement of Concepts No.2), konservatisme didefinisikan sebagai "reaksi kehati-hatian terhadap ketidakpastian untuk memastikan bahwa ketidakpastian dan risiko yang melekat dalam bisnis dipertimbangkan secara memadai". IFRS Framework (1989) juga mengacu pada kehatihatian, dengan nuansa yang lebih banyak:

Reliability is affected by the use of estimates and by uncertainties associated with items recognized and measured in financial statements. These uncertainties are dealt with, in part, by disclosure and, in part, by exercising prudence in preparing financial statements. Prudence is the inclusion of a degree of caution in the exercise of judgments needed in making the estimates required under conditions of uncertainty, such that assets or income are not overstated and liabilities or expenses are not understated. However, prudence can only be exercised within the context of the other qualitative characteristics in framework, particularly relevance and the faithful representation of transaction in financial statements would not be neutral and, not have the quality of reliability.[IFRS Foundation, F, hal. 36-37] 
Apapun pengertian kehati-hatian, satu konsekuensi umum dan paling terlihat dari akuntansi konservatif adalah penilaian yang lebih rendah terhadap aset bersih perusahaan (Watts, 2003; Givoly, 2007). Literatur akademik mengklasifikasikan konservatisme menjadi dua, yaitu konservatisme yang kondisional (conditional conservatism) dan konservatisme yang tidak kondisional (unconditional conservatism).

Konservatisme yang kondisional adalah menurunkan nilai aset dilakukan sebagai reaksi terhadap berita buruk. Konservatisme ini mensyaratkan tingkat verifikasi yang lebih tinggi terhadap pengakuan keuntungan dibandingkan pengakuan kerugian: kerugian diakui sesegera mungkin, sedangkan keuntungan dapat diakui sebagai pendapatan jika sudah pasti. Kondisi ini dipenuhi jika pendapatan tersebut disertai dengan arus kas masuk, atau dijamin oleh kontrak (misal, penjualan yang dikirim dengan faktur). Konservatisme ini juga disebut konservatisme "news dependent", hal ini menyebabkan pengakuan buku akrual dapat dibalik untuk mengantisipasi kerugian transaksi masa depan yang dilakukan oleh perusahaan. Contoh, pencatatan persediaan menggunakan nilai realisasi bersih neto dan impairment aset tetap.

Sedangkan konservatisme yang tidak kondisional, penurunan nilai aset bukan merupakan reaksi terhadap suatu berita buruk, contohnnya adalah metode penyusutan yang diakselerasi seperti saldo menurun berganda, tidak mengakui aset tidak berwujud, membiayakan pengeluaran untuk riset dan pengembangan. Beberapa, ukuran yang sering digunakan dalam literatur untuk mengukur konservatisme yang tidak kondisonal, seperti akrual yang terus-menerus negatif (Givoly et. al, 2000; Ahmed et. al., 2002), atau lebih umum penyajian lebih untuk rasio market-to-book (Beaver and Ryan, 2000).

Relevansi dan keandalan informasi adalah kunci dalam proses pengambilan keputusan bagi investor. Namun demikian, prinsip kehati-hatian tidak sepenting negara-negara yang beroperasi di bawah model estimasi akuntansi kontinental. Meskipun International Accounting Standards Board (IASB) mendukung penggunaan kehatihatian dalam kasus ketidakpastian, menegaskan bahwa itu bukan karakteristik kualitatif yang diperlukan. Namun, konservatisme selalu memainkan peran utama dalam praktik akuntansi. Memang, fakta bahwa konservatisme sering diakui sebagai prinsip dasar untuk praktik akuntansi telah mempengaruhi teori akuntansi (Basu1997).

Watts (2003) menganggap praktik akuntansi konservatif sebagai mekanisme yang efektif untuk menyiapkan informasi keuangan. Konservatisme akuntansi mengarah ke informasi 
keuangan yang dapat diandalkan karena memerlukan tingkat kontrol yang lebih tinggi sehingga risiko kesalahan minimal. Selain itu, konservatisme telah sering digunakan sebagai ukuran kualitas untuk informasi keuangan (Francis, Lafond, Olsson dan Schipper 2004; Cheng dan Liu 2007). Byungcherl (2012) mempelajari implikasi konservatisme akuntansi pada ketepatan perkiraan yang disajikan oleh analis keuangan dan menemukan bahwa analis keuangan menggabungkan konservatisme akuntansi dalam meramalkan hasil perusahaan. Selain itu, mereka menghadapi lebih banyak kesulitan sambil memperkirakan hasil perusahaan yang kurang konservatif.

Standar akuntansi secara langsung maupun tidak langsung mempengaruhi tingkat konservatisme akuntansi. Oleh karena itu standar akuntansi memiliki peran penting dalam menyiapkan laporan keuangan, untuk mengontrol optimisme manajer yang berlebihan (Sterling 1967; Grambovas et al. 2006). Lang, Raedy, dan Yetman (2003) dalam penelitiannya terhadap perusahaan-perusahaan yang terdaftar di AS menyatakan tingkat konservatisme yang tinggi merupakan tekanan penting bagi kualitas informasi yang mereka komunikasikan. Lobo dan Zhou (2006) juga menganalisis konservatisme akuntansi sebelum dan sesudah diberlakukannya undang-undang $\mathrm{SOX}^{2}$, mencatat bahwa peningkatan tingkat konservatisme akuntansi setelah penerapan undang-undang tersebut.

\section{Struktur Kepemilikan (Ownership Structure)}

$$
\text { Beberapa studi menunjukkan bukti }
$$
empiris bahwa faktor standar akuntansi saja (termasuk IFRS) tidak cukup untuk menentukan kualitas informasi akuntansi. Penelitian Karampinis \& Hevas (2011) menyimpulkan lingkungan institusional juga ikut menentukan kualitas akuntansi. Sistem hukum dan politik yang berlaku dalam suatu negara juga merupakan faktor penting bagi penentu kualitas akuntansi selain standar akuntansi ${ }^{3}$ (Soderstrom \& Sun, 2007), sehingga dalam menganalisis kualitas informasi sebagai dampak adopsi IFRS, ada beberapa faktor yang turut menentukan kualitas informasi tersebut.

Dalam literatur bisnis internasional, Indonesia diklasifikasikan dalam kluster negara-

\footnotetext{
${ }^{2}$ The Sarbanes-Oxley Act adalah Undang-undang tentang reformasi akuntansi bagi perusahaan yang terdaftar dan perlindungan dari investor yang diumumkan pada tanggal 31 Juli 2002 di Amerika Serikat.

${ }^{3}$ Faktor-faktor ini dapat berinteraksi satu sama lain untuk mempengaruhi kualitas laba. Burgstahler et al. (2007) menguji hubungan antara manajemen laba dan interaksi antara struktur kepemilikan, struktur dan pengembangan pasar modal, sistem pajak, standar akuntansi, dan perlindungan investor. Ding et. al. (2007) meneliti bagaimana sistem hukum negara, pembangunan ekonomi, pentingnya pasar modal, dan konsentrasi kepemilikan membentuk standar akuntansi negara, yang pada gilirannya mempengaruhi kualitas negara pelaporan keuangan.
} 
negara code law (La Porta et. al., 1998). Negaranegara dalam kluster ini mempunyai fungsi perbankan yang lebih dominan daripada pasar modal dalam memenuhi kebutuhan pendanaan perusahaan, sehingga kebutuhan pengungkapan publik (public disclosure) menjadi kurang penting di negara-negara code law dibanding negara-negara common law. Negara-negara dalam kluster code law pada umumnya mempunyai tingkat perlindungan investor yang lemah dan sistem hukum yang kurang berjalan baik. Sistem hukum dan politik dapat mempengaruhi kualitas laba secara tidak langsung melalui struktur kepemilikan. La Porta et al. (1998) menemukan bahwa negara-negara dengan perlindungan investor yang lebih kuat memiliki konsentrasi kepemilikan yang lebih rendah. Lemahnya perlindungan investor menyebabkan kepemilikan yang terkonsentrasi. Hal ini sesuai dengan temuan Siregar dan Utama (2008) yang menunjukkan besarnya persentase kepemilikan pemegang saham mayoritas.

\section{Pengembangan Hipotesis}

Nobes (2010) dalam bukunya menyatakan bahwa, Standar Akuntansi Internasional mempunyai peran penting pada negara berkembang. Adopsi IFRS merupakan jalan termurah untuk negara-negara ini daripada menyiapkan standar sendiri. Adopsi IFRS juga memberikan manfaat yang lebih besar dan lebih mudah bagi perusahaan domestik dan luar negeri atau profesi akuntan.

$$
\text { Indonesia sebagai anggota IFAC }
$$

(International Federation of Accountant), yang tergabung sejak tahun 1987, memiliki keterkaitan yang cukup erat dengan insiatif implementasi IFRS dan dibandingkan dengan negara-negara di ASEAN dapat dikatakan bahwa Indonesia memiliki keterkaitan yang lebih kuat dalam implementasi IFRS. Hal ini juga seiring dengan keterlibatan Indonesia dalam G20 (Group of 20 Leaders). Masukan dan rekomendasi G20 menjadi acuan bagi IASB dalam menyusun aktivitas-aktivitasnya. Salah satu rekomendasi G20 adalah menegaskan perlunya IASB dan FASB menggandakan usahausaha dalam rangka konvergensi standar akuntansi keuangan, dan meminta kedua dewan untuk dapat menyelesaikan proyek pengembangan konvergensi tersebut pada bulan Juni 2011.

Berdasarkan pemaparan di atas, maka hipotesis yang diajukan dalam penelitian ini adalah:

\section{H: Konservatisme informasi akuntansi perusahaan meningkat setelah laporan keuangan disajikan menggunakan standar akuntansi hasil adopsi IFRS.}

\section{Metode Penelitian}

Penentuan Sampel dan Sumber Data 
Populasi dalam penelitian ini adalah laporan keuangan perusahaan yang go public di Bursa Efek Indonesia. Pemilihan sampel dilakukan dengan menggunakan metode purposive sampling, yaitu metode pemilihan sampel berdasarkan kriteria yang telah ditentukan. Adapun kriteria tersebut adalah sebagai berikut: 1) Perusahaan terdaftar di Bursa Efek Indonesia; 2) Perusahaan tersebut mempublikasikan data laporan keuangan yang telah diaudit mulai tahun 2007 sampai dengan tahun 2016; dan 3) Laporan keuangan perusahaan pada periode yang diteliti harus memiliki informasi yang dibutuhkan sebagai proksi variabel dalam penelitian.

Penelitian ini menguji kualitas pelaporan keuangan periode 2007-2016, karena mulai tahun 2012 terjadi perubahan yang sangat signifikan terhadap Standar Akuntansi Keuangan (SAK) di Indonesia yaitu adopsi IFRS ke dalam SAK. Adopsi penuh IFRS di Indonesia dilakukan pada tahun 2012. Oleh karena itu, periode setelah adopsi dipilih tahun 2012 sampai dengan 2016. Untuk memperoleh observasi waktu yang seimbang, maka periode sebelum adopsi dipilih tahun 2007 sampai 2011. Sehingga, penelitian ini menggunakan sampel sebanyak 1.780 dari 178 perusahaan yang terdaftar di BEI pada tahun 2006-2016 atau sebanyak 12.460 observasi. Sumber data utama yang digunakan untuk menganalisis konservatisme adalah Laporan keuangan yang bersumber dari Indonesian Capital Market Directory (ICMD), Database BEI, dan Website perusahaan.

\section{Definisi dan Pengukuran Variabel Variabel Dependen}

Variabel dependen pada penelitian ini adalah kualitas pelaporan keuangan (financial reporting quality) yang diproksikan dengan konservatisme akuntansi. Konservatisme oleh IASB diartikan sebagai tingkat kehati-hatian dalam penilaian yang diperlukan untuk membuat perkiraan yang diperlukan dalam kondisi ketidakpastian, sehingga aset atau pendapatan tidak terlalu besar dan kewajiban atau beban tidak terlalu rendah (IASB, 1989, paragraph 37).

Beaver dan Ryan (2000) mengembangkan perbaikan dalam penggunaan Market-to-Book (MTB) sebagai ukuran konservatisme, yang telah cukup banyak diterapkan dalam literatur. Perbaikan ini menguraikan rasio MTB menjadi dua komponen, komponen bias dan komponen lag. Beaver dan Ryan (2000) berpendapat bahwa komponen bias MTB ditafsirkan sebagai ukuran konservatisme akuntansi. Untuk mengurai MTB, Beaver dan Ryan (2000) me-regresikan MTB pada serangkaian lag pengembalian saham sebelumnya, yang mengarah pada 6 tahun lag tahun sebelumnya, seperti berikut dampak regresi data panel: 


$$
M T B_{i, t}=\alpha_{t}+\alpha_{i}+\sum_{j=0}^{6} \beta_{j} R_{i, t-j}+\varepsilon_{i, t}
$$

Keterangan:

$$
\begin{aligned}
\text { MTB }_{\mathrm{t}, \mathrm{I}}= & \text { Rasio Market-to-Book } \\
& \text { perusahaan } \mathrm{i} \text {, pada akhir tahun } \mathrm{t} \\
\alpha_{t}= & \text { Variasi tahun ke tahun dalam MTB } \\
& \text { dengan menggunakan sampel perusahaan } \\
\alpha_{i}= & \text { Komponen bias MTB untuk perusahaan } \mathrm{i} \\
R_{t-j, i}= & \text { Return on Equity (ROE) selama } 6 \text { tahun } \\
& \text { sebelumnya } \\
\beta_{j}= & \text { Koefisien regresi dalam } R_{t-j, i}
\end{aligned}
$$

Berdasarkan regresi di atas, $\alpha_{t}$ menggambarkan efek waktu saat pergerakan MTB pasar secara luas dan sementara itu tetap untuk setiap tahun tertentu, itu bisa berubah dari tahun ke tahun. Koefisien efek tetap, $\alpha_{i}$ merupakan firm-spesific komponen bias dari MTB perusahaan i, dan tetap untuk setiap perusahaan $\beta_{j}$ adalah koefisen regresi dari komponen rasio MTB. Berdasarkan Beaver dan Ryan (2000), komponen bias MTB, $\alpha_{i}$ adalah pengukuran yang lebih akurat dari tingkat konservatisme perusahaan daripada MTB baku.

\section{Variabel Independen}

\section{Adopsi IFRS}

Variabel independen pada penelitian ini adalah adopsi IFRS. Variabel adopsi IFRS dalam penelitian ini diukur dengan menggunakan variabel dummy, dimana angka 1 untuk periode penyajian laporan keuangan dengan menggunakan standar hasil adopsi dari IFRS yaitu 2012- 2016 dan angka 0 untuk periode 2007-2011 (penyajian laporan keuangan dengan menggunakan standar sebelum adopsi IFRS).

\section{Struktur Kepemilikan (Ownership Structure)}

Penetapan standar akuntansi adalah proses politik, dimana pengguna akuntansi seperti otoritas pajak, bank, pemegang saham, manajer, dan serikat buruh memiliki pengaruh signifikan terhadap penyusun standar. Sistem hukum juga mempengaruhi standar akuntansi. IFRS disusun berdasar kerangka konseptual yang mirip dengan kerangka konseptual standar akuntansi negaranegara common law (Barth et. al, 2008). Sistem keuangan negara-negara common law cenderung berorientasi pada pemegang saham. Penyusunan standar akuntansi diserahkan kepada lembaga profesional swasta dan bertujuan untuk memenuhi kebutuhan informasi bagi investor. Pasar modal memiliki peran utama dalam pendanaan perusahaan sehingga pengungkapan kepada publik merupakan prasyarat wajib bagi pelaporan keuangan. Dalam negara-negara code law pada umumnya mempunyai model sistem keuangan yang lebih berorientasi pada pemangku kepentingan. Standar akuntansi disusun oleh lembaga regulasi yang dikendalikan oleh negara melalui perundangundangan yang detil untuk mencapai 
keseragaman. Pendanaan perusahaan sangat menggantungkan pada perbankan sehingga pasar modal menjadi pilihan kedua (Karampinis dan Hevas, 2011). Besarnya intervensi pemerintah dalam penyusunan standar akuntansi dan dominasi perbankan dalam pendanaan perusahaan menyebabkan pelaporan keuangan berorientasi pada kreditur dan pajak.

\section{Kepemilikan Manajerial (Managerial Ownership)}

Kepemilikan manajerial adalah kepemilikan saham oleh pihak manajemen yang secara aktif berpartisipasi dalam pengambilan keputusan perusahaan, terdiri dari direktur dan komisaris. Variabel ini diukur dengan persentase jumlah saham yang dimiliki oleh manajemen terhadap seluruh jumlah modal saham perusahaan.

Laba merupakan salah satu informasi potensial yang terkandung di dalam laporan keuangan dan sangat penting bagi para pengguna laporan keuangan. Jika kepemilikan manajerial rendah, maka manajer memiliki kecenderungan melaporkan laba yang optimis agar kinerja yang mereka capai dinilai baik oleh pemegang saham eksternal. Hal ini akan sangat berpengaruh terhadap besarnya bonus yang akan diterima oleh manajemen. Sebaliknya apabila kepemilikan saham oleh manajerial rendah maka perusahaan akan semakin konservatif, karena laba bukanlah satu-satunya hal yang menarik perhatian mereka tetapi kontinuitas perusahaan lebih penting.

\section{Kepemilikan Institusional (Institutional Ownership)}

Kepemilikan institusional adalah jumlah kepemilikan saham perusahaan oleh investor institusi. Variabel ini diukur dengan persentase jumlah saham yang dimiliki oleh institusi terhadap seluruh jumlah modal saham perusahaan. Kepemilikan institusional memiliki kemampuan untuk mengendalikan pihak manajemen melalui proses monitoring secara efektif sehingga mengurangi tindakan manajemen melakukan manajemen laba (Budiono, 2005).

\section{Kepemilikan Publik (Public Ownership)}

Kepemilikan publik merupakan jumlah kepemilikan saham perusahaan oleh investor publik. Variabel ini diukur dengan persentase jumlah saham yang dimiliki oleh publik terhadap seluruh jumlah modal saham perusahaan. Publik memiliki kecenderungan mengingini laba yang besar agar mendapatkan dividen atau capital gain yang besar pula. Seringkali mereka hanya berfokus pada kepentingan jangka pendek untuk segera mendapatkan retur. Hal ini mendorong perusahaan untuk melaporkan laba kurang konservatif untuk perusahaan dengan struktur kepemilikan publik yang tinggi. 
DOI: http://dx.doi.org/10.25181/esai.v12i2.1093

\section{Variabel Kontrol}

Size

Size merupakan variabel kontrol yang digunakan untuk mengontrol variasi ukuran perusahaan. Variabel ini diukur dengan me-log total aset perusahaan. Log total aset merefleksikan ukuran perusahaan. Konsisten dengan penelitian terdahulu yang dilakukan oleh (Andre, 2013); (Hung and Subramayam, 2004); $\mathrm{Lu}$ (2012) menggunakan variabel ini untuk mengontrol ukuran perusahaan. Ukuran perusahaan akan mempengaruhi tingkat biaya politis yang akan dihadapi perusahaan sehingga akan mempengaruhi penggunaan prinsip akuntansi yang konservatif (Watts and Zimmerman, 1978).

\section{Leverage}

Leverage merupakan variabel kontrol yang digunakan untuk mengontrol variasi struktur modal perusahaan. Variabel ini diukur dengan membagi total liabilitas dengan total aset perusahaan. Leverage merupakan pendanaan perusahaan yang berasal dari utang pihak luar, digunakan untuk mengendalikan peran debtholder dalam memilih metode akuntansi yang konservatif karena pemilihan tersebut tergantung dari tingkat leverage perusahaan.

\section{Spesifikasi Model}

Penelitian ini menguji perubahan kualitas informasi akuntansi pelaporan keuangan perusahaan manufaktur di Indonesia periode 2010-2013, dengan menggunakan model analisis regresi sebagai berkut:

$$
\begin{aligned}
\operatorname{CONS}_{\mathrm{i}, \mathrm{t}}= & \beta_{0}+\beta_{1} \mathrm{IFRS}_{\mathrm{i}, \mathrm{t}}+\beta_{2} \mathrm{MO}_{\mathrm{i}, \mathrm{t}}+\beta_{3} \mathrm{IO}_{\mathrm{i}, \mathrm{t}}+\beta_{4} \\
& \mathrm{PO}_{\mathrm{i}, \mathrm{t}}+\beta_{5} \operatorname{Size}_{\mathrm{i}, \mathrm{t}}+\beta_{6} \operatorname{Lev}_{\mathrm{i}, \mathrm{t}}+\varepsilon_{\mathrm{i}, \mathrm{t}} .
\end{aligned}
$$

Keterangan:

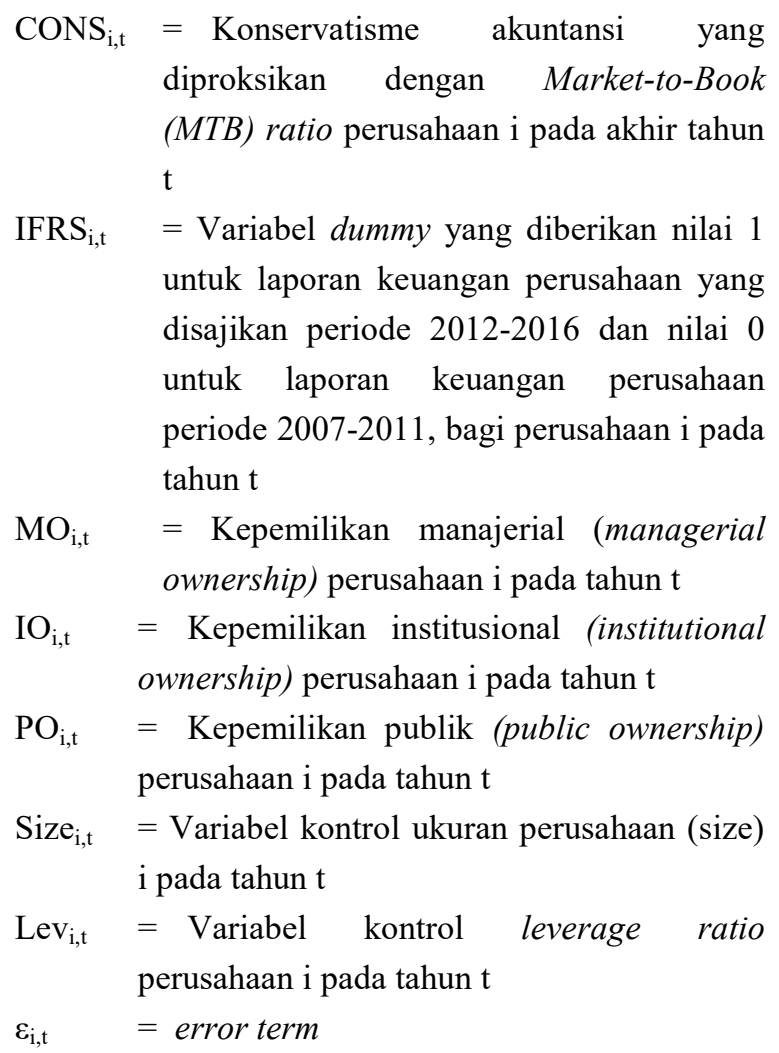

\section{Hasil Dan Pembahasan}

Statistik Deskriptif untuk Variabel Dependen dan Independen

Statistik deskriptif untuk variabel yang digunakan dalam pengujian hipotesis, baik variabel dependen maupun independen disajikan dalam tabel 4.1 
Tabel 4.1

Statistik Deskriptif

\begin{tabular}{lcccccccc}
\hline & \multicolumn{3}{c}{ Sebelum Adopsi IFRS } & \multicolumn{4}{c}{ Setelah Adopsi IFRS } \\
Variabel & Min. & Max. & Mean & Std. Dev. & Min. & Max. & Mean & Std. Dev. \\
\hline CONS $_{\mathrm{i}, \mathrm{t}}$ & $-1,90$ & 2,48 & 0,0067 & 0,71447 & $-1,98$ & 2,36 & 0,0290 & 0,45895 \\
$\mathrm{IFRS}_{\mathrm{i}, \mathrm{t}}$ & 0,00 & 0,00 & 0,0000 & 0,00000 & 1 & 1 & 1 & 0,00000 \\
MO $_{\mathrm{i}, \mathrm{t}}$ & 0,00 & 0,76 & 0,0291 & 0,10183 & 0,00 & 0,89 & 0,0360 & 0,12513 \\
$\mathrm{IO}_{\mathrm{i}, \mathrm{t}}$ & 0,00 & 0,99 & 0,6253 & 0,27032 & 0,00 & 1,00 & 0,6392 & 0,25517 \\
PO $_{\mathrm{i}, \mathrm{t}}$ & 0,00 & 1,00 & 0,2646 & 0,17614 & 0,00 & 0,87 & 0,2753 & 0,16991 \\
Size $_{\mathrm{i}, \mathrm{t}}$ & 2,95 & 8,71 & 6,0532 & 0,74230 & 3,21 & 9,57 & 6,4663 & 0,87054 \\
Lev $_{\mathrm{i}, \mathrm{t}}$ & 0,00 & 6,78 & 0,5734 & 0,47231 & 0,01 & 7,48 & 0,5518 & 0,50056 \\
\hline
\end{tabular}

Sumber: Data penelitian, diolah.

Tabel 4.1 menggambarkan statistik deskriptif pada periode sebelum dan setelah adopsi IFRS. Berdasarkan tabel tersebut menunjukkan bahwa semua variabel yang digunakan dalam model penelitian memiliki rentang variasi yang masuk akal. Tabel 4.1 melaporkan mean sebelum (sesudah) adopsi untuk variabel dependen CONS untuk periode 2007 sampai dengan 2016 adalah sebesar 0,0067 $(0,0290)$, sedangkan variabel independen MO, IO, PO masing-masing memiliki kisaran mean sebesar 0,0291 (0,0360); 0,6253 (0,6392); dan 0,2646 (0,2753). Mean untuk kedua variabel kontrol Size dan Lev adalah 6,0532 $(6,4663)$ dan $0,5734(0,5518)$.

Sebelum dilakukan pengolahan data, peneliti melakukan pemeriksaan awal terhadap data untuk mengidentifikasi ada tidaknya outlier. Selanjutnya, dilakukan pengujian asumsi klasik. Hasil pengujian menunjukkan bahwa tidak ada pelanggaran yang cukup berarti pada normalitas, autokorelasi, multikolinieritas, dan heteroskedastisitas.

\section{Korelasi Bivariat}

Menurut Gujarati (2003), model asumsi klasik regresi linear mengharuskan tidak ada hubungan linear sempurna antar variabel independen. Adanya multikolinieritas yang kuat mengakibatkan ketidaktepatan estimasi. Model regresi yang baik seharusnya tidak terjadi korelasi diantara variabel independen. Uji Pearson dan Spearman diantara variabel dihitung dan disajikan pada Tabel 4.2. Pengujian terhadap matriks korelasi untuk variabelvariabel independen menunjukkan tidak ada masalah multikolinearitas, tidak ada koefisien korelasi di atas 0,9 . 
Tabel 4.2

Korelasi Bivariat

\begin{tabular}{|c|c|c|c|c|c|c|c|}
\hline & $\mathrm{CONS}_{\mathrm{i}, \mathrm{t}}$ & IFRS $_{i, t}$ & $\mathrm{MO}_{\mathrm{i}, \mathrm{t}}$ & $\mathrm{IO}_{\mathrm{i}, \mathrm{t}}$ & $\mathrm{PO}_{\mathrm{i}, \mathrm{t}}$ & Size $_{i, t}$ & $\operatorname{Lev}_{i, t}$ \\
\hline \multicolumn{8}{|c|}{$\mathrm{CONS}_{\mathrm{i}, \mathrm{t}}$} \\
\hline IFRS $_{i, t}$ & 0,19 & & & & & & \\
\hline $\mathrm{MO}_{\mathrm{i}, \mathrm{t}}$ & $-0,009$ & 0,03 & & & & & \\
\hline $\mathrm{IO}_{\mathrm{i}, \mathrm{t}}$ & 0,004 & 0,026 & $-0,373 * *$ & & & & \\
\hline $\mathrm{PO}_{\mathrm{i}, \mathrm{t}}$ & $-0,001$ & 0,031 & $-0,047 *$ & $-0,513 *$ & & & \\
\hline Size $_{i, t}$ & 0,016 & $0,247 * *$ & $-0,105 * *$ & $-0,044 *$ & $0,163 * *$ & & \\
\hline $\operatorname{Lev}_{i, t}$ & $-0,028$ & $-0,022$ & $-0,039$ & $0,058 * *$ & 0,008 & $-0,098 * *$ & \\
\hline
\end{tabular}

**. Correlation is significant at the 0.01 level (1-tailed)

*. Correlation is significant at the 0.05 level (1-tailed)

Uji multikolinieritas juga dilakukan dengan melihat nilai tolerance dan variance inflation factor (VIF). Jika nilai tolerance $>0,10$ dan VIF $<10$, maka dapat diartikan bahwa tidak terdapat multikolinearitas pada penelitian tersebut. Sebaliknya jika tolerance $<0,10$ dan
VIF $>10$, maka terjadi gangguan multikolinieritas pada penelitian tersebut (Ghozali, 2011). Hasil uji multikolinieritas untuk model pengukuran konservatisme menunjukkan nilai VIF tidak lebih dari 10 dan nilai tolerance berada di atas 0,1 (Tabel 4.3).

Tabel 4.3

Uji Multikolinearitas

\begin{tabular}{|c|c|c|c|c|}
\hline & \multirow[t]{2}{*}{$\mathbf{t}$} & \multirow[t]{2}{*}{ Sig. } & \multicolumn{2}{|c|}{ Collinearity Statistics } \\
\hline & & & Tolerance & $\boldsymbol{V I F}$ \\
\hline Konstanta & $-0,071$ & 0,943 & & \\
\hline IFRS $_{\mathrm{i}, \mathrm{t}}$ & 0,642 & 0,521 & 0.930 & 1,075 \\
\hline $\mathrm{MO}_{\mathrm{i}, \mathrm{t}}$ & $-0,367$ & 0,7140 & 0,772 & 1,295 \\
\hline $\mathrm{IO}_{\mathrm{i}, \mathrm{t}}$ & 0,004 & 0,997 & 0,574 & 1,743 \\
\hline $\mathrm{PO}_{\mathrm{i}, \mathrm{t}}$ & $-0,107$ & 0,914 & 0,657 & 1,523 \\
\hline Size $_{i, t}$ & 0,355 & 0,723 & 0,894 & 1,119 \\
\hline $\operatorname{Lev}_{i, t}$ & $-1,110$ & 0,267 & 0,984 & 1,017 \\
\hline
\end{tabular}

Sumber: Data Penelitian, diolah.

Hal ini mengindikasikan bahwa tidak terdapat masalah multikolinieritas dalam penelitian ini.

\section{Analisis Regresi}

Pengujian hipotesis pada penelitian ini untuk menguji secara empiris bahwa adopsi
IFRS mampu mempengaruhi tingkat konservatisme informasi akuntansi. Pada penelitian ini penulis menggunakan variabel dummy untuk membedakan sebelum dan setelah adopsi IFRS yaitu 1 untuk periode 2012-2016 dan 0 untuk periode 2007-2011. 
DOI: http://dx.doi.org/10.25181/esai.v12i2.1093

Tabel 4.4 menyajikan hasil regresi OLS (Ordinary Least Square) yang digunakan untuk menguji hubungan antara konservatisme akuntansi terhadap penggunaan standar akuntansi hasil adopsi IFRS, kepemilikan manajerial, kepemilikan institusional, dan kepemilikan publik sebagai variabel independen, yang dikontrol dengan ukuran perusahaan (size) dan komposisi utang (leverage). Tabel tersebut menunjukkan bahwa koefisien determinasi $\left(\mathrm{R}^{2}\right)$ sebesar 5,8\%, yang menjelaskan hubungan antara variabel dependen dan independen dalam model pengujian sebesar nilai tersebut. Secara umum, koefisien determinasi untuk data silang (crossection) relatif rendah karena adanya variasi yang besar antara masing-masing pengamatan. Koefisien determinasi $\left(\mathrm{R}^{2}\right)$ hanyalah salah satu dan bukan satu-satunya kriteria memilih model yang baik, karena walaupun regresi linear menghasilkan koefisien determinasi yang tinggi namun tidak lolos uji asumsi klasik maka model tersebut bukanlah model penaksir yang baik dan seharusnya tidak dipilih menjadi model empirik (Insukindro, 1998).

Tabel 4.4 Analisis Regresi

\begin{tabular}{cccc}
\hline $\mathrm{CONS}_{\mathrm{i}, \mathrm{t}}=\beta_{0}+\beta_{1} \mathrm{IFRS}_{\mathrm{i}, \mathrm{t}}+\beta_{2} \mathrm{MO}_{\mathrm{i}, \mathrm{t}}+\beta_{3} \mathrm{IO}_{\mathrm{i}, \mathrm{t}}+\beta_{4} \mathrm{PO}_{\mathrm{i}, \mathrm{t}}+\beta_{5} \mathrm{Size}_{\mathrm{i}, \mathrm{t}}+\beta_{6} \mathrm{Lev}_{\mathrm{i}, \mathrm{t}}+\varepsilon_{\mathrm{i}, \mathrm{t}}$ \\
\hline Variabel & Koefisien & Nilai t & Nilai P \\
\hline Konstanta & $-0,419$ & $-2,577$ & 0,0102 \\
IFRS & $-0,157$ & $-436,949$ & 0,0000 \\
MO & 0,046 & 1,695121 & 0,0906 \\
IO & 0,101 & 4,853441 & 0,0000 \\
PO & 0,035 & 0,809929 & 0,4183 \\
Size & 0,070 & 2,545677 & 0,0112 \\
Lev & 0,051 & 3,532342 & 0,0004 \\
Adj. $\mathrm{R}^{2}$ & 0,058 & & \\
F-statistik & 6,451 & & 0,0000 \\
\hline
\end{tabular}

Sumber: Data Penelitian, diolah.

\begin{abstract}
Pada tabel 4.4 dapat dilihat bahwa koefisien $\mathrm{CONS}_{\mathrm{i}, \mathrm{t}}{ }^{*}$ IFRS bernilai negatif $(\rho=0,0000)$. Secara statistik hal ini menunjukkan bahwa variabel $\mathrm{CONS}_{\mathrm{i}, \mathrm{t}}$ dan IFRS berpengaruh negatif signifikan terhadap $\mathrm{CONS}_{\mathrm{i}, \mathrm{t}}$. Oleh
\end{abstract}

karena itu, dapat disimpulkan bahwa adopsi IFRS berpengaruh negatif terhadap konservatisme akuntansi, artinya bahwa adopsi IFRS tidak meningkatkan konservatisme akuntansi bahkan justru menurunkannya. Dengan demikian hipotesis penelitian ini tidak 
terdukung oleh data observasi. Hasil penelitian ini justru konsisten dan mengkonfirmasi penelitian dilakukan oleh (2012) bahwa konservatisme menurun setelah adopsi IFRS. Penurunan tingkat konservatisme setelah adopsi IFRS lebih penting bagi negara-negara dengan standar lokal yang secara signifikan berbeda dari Standar Internasional. Zeghal et., al. (2016) menyatakan telah terjadi penurunan tingkat konservatisme pada periode setelah adopsi IFRS. Pengakuan berita buruk daripada berita baik menurun ketika laporan keuangan disusun berdasarkan IFRS. Seperti halnya dengan penelitian Paananen dan Lin (2009), yang membuktikan bahwa pengenalan berita buruk berkurang setelah adopsi IFRS. Terjadi peningkatan akrual diskresioner dalam setelah adopsi IFRS, yang berarti penurunan tingkat konservatisme.

Variabel lain yang menjadi pusat pembahasan adalah struktur kepemilikan yang diwakili oleh kepemilikan manajerial, kepemilikan institusional, dan kepemilikan publik. Koefisien interaksi $\mathrm{CONS}_{\mathrm{i}, \mathrm{t}}{ }^{\mathrm{M}} \mathrm{MO}$, $\mathrm{CONS}_{\mathrm{i}, \mathrm{t}}$ *IO, dan $\mathrm{CONS}_{\mathrm{i}, \mathrm{t}}$ PO bernilai positif dan siginifikan masing-masing pada level 10\%, $1 \%$, dan 5\%. Hal ini menunjukkan bahwa kepemilikan manajerial, institusional, dan kepemilikan publik mampu mendorong peningkatan konservatisme informasi akuntansi.
Untuk variabel kontrol yang digunakan dalam model penelitian $\left(\mathrm{CONS}_{\mathrm{i}, \mathrm{t}} *\right.$ Size dan $\left.\mathrm{CONS}_{\mathrm{i}, \mathrm{t}}{ }^{*} \mathrm{Lev}\right)$, hasil regresi menunjukkan koefisien positif dan signifikan pada level $1 \%$. Hal ini menunjukkan semakin besar ukuran perusahaan dan rasio utang perusahaan, semakin mendorong peningkatan tingkat konservatisme akuntansi.

Berdasarkan hasil analisis regresi dengan menggunakan model penelitian, peneliti berpendapat bahwa konservatisme atau 'kehatihatian' (prudence), yang diyakini sebagai salah satu prinsip tertua dan merupakan dimensi keandalan karakteristik kualitatif laporan keuangan, yang mempengaruhi praktik akuntansi seharusnya mampu meningkatkan konservatisme informasi akuntansi. Oleh karena itu, penelitian ini menghipotesiskan konservatisme akuntansi akan meningkat setelah laporan akuntansi disusun dengan menggunakan standar hasil adopsi IFRS. Namun setelah berlakunya kerangka konseptual IASB dan FASB yang diadopsi pada bulan September 2010, justru konservatisme atau 'kehati-hatian' tidak dimasukkan sebagai kualitas pelaporan keuangan (IASB, 2010). IASB menganggap 'faithful representation' sebagai sebuah karakteristik kualitatif fundamental dari informasi keuangan yang memfokuskan pada kelengkapan (completeness), netralitas 
DOI: http://dx.doi.org/10.25181/esai.v12i2.1093

(neutrality), dan kebebasan dari kesalahan (feedrom of error).

\section{Kesimpulan}

Penelitian ini bertujuan untuk menemukan bukti mengenai dampak penggunaan Standar Akuntansi Keuangan (SAK) hasil adopsi IFRS (International Financial Reporting Standards) terhadap perubahan tingkat konservatisme informasi akuntansi perusahaan di Indonesia. Hasil penelitian ini menunjukkan bahwa adopsi IFRS tidak meningkatkan tingkat konservatisme akuntansi, hipotesis yang diajukan dalam penelitian ini tidak terdukung.

Penelitian ini memiliki beberapa keterbatasan, sehingga membuka peluang bagi penelitian di masa mendatang. Pertama, rentang waktu penelitian lima tahun sebelum adopsi dan lima tahun setelah adopsi. Periode lima tahun merupakan periode yang terlalu singkat. Penelitian dilakukan ketika perusahaan masih menerapkan IFRS secara bertahap, artinya belum semua standar akuntansi IFRS diadopsi dan perusahaan juga sedang dalam transisi penggunaan standar akuntansi baru, sehingga kemungkinan pengaruhnya terhadap konservatisme belum bisa secara akurat diinvestigasi. Penelitian lanjutan bisa dilakukan dengan mempertimbangkan periode waktu yang lebih panjang. Kedua, Penelitian ini hanya menggunakan sampel perusahaan manufaktur, mungkin akan berbeda hasilnya apabila menggunakan data seluruh industri. Penelitian selanjutnya menggunakan data seluruh industri agar hasil penelitian menjadi lebih komprehensif dan dapat digeneralisir. Ketiga, penelitian ini tidak memperhitungkan faktor-faktor lain yang dapat mempengaruhi konservatisme akuntansi, terutama faktor institusional, kepastian hukum, perlindungan terhadap investor, dan faktorfaktor lain yang turut mempengaruhi kondisi ekonomi Indonesia.

\section{Daftar Pustaka}

Ahmed, A., Billings, B., B., Morton, R., and Stanford-Harris, M. (2002). The role of accounting conservatism in mitigating bondholder conflict over dividend policy and in reducing debt costs. The Accounting Review, 77 (4), 867-890.

Ahmed, A. S., Neel, M., and Wang, D. (2013). Does mandatory adoptionof IFRS improve accounting quality? Preliminary evidence. Contemporary Accounting Research, 30(4), 1344-1372.

Andre, P., Filip, A., and Paugam, L. (2013). Impact of mandatory IFRS adoption on conditional conservatism in Europe. Working Paper, ESSEC Business School.

Ball, R., S., Kothari, and A. Robin (2000). The effect of international institutional factors of properties accounting earnings. Journal of Accounting and Economics, 29, 1-51.

Ball, R., A. Robin and J.S. Wu. (2003). Incentives versus standards: Properties of accounting income in four east asian 
countries. Journal of Accounting and Economics 3, 235-270.

Ball, R., and Shivakumar, L. (2005). Earning quality in UK privat firms: comparative loss recognition timeliness. Journal of accounting and economics, 39 (1), 83-128.

Ball, R., and Shivakumar, L. (2006). The role of accruals in asymmetrically timely gain and loss recognition. Journal of Accounting Research 44 (2), 207-242.

Barth, M. E., W. R. Landsman, and M. H. Lang. (2008). International accounting standards and accounting quality. Journal of Accounting Research, 46(3), 467-498.

Basu,S., (1997). The conservatism principle and the asymetric timeliness of earnings. Journal of Accounting and Economics 24, 3-37.

Beaver, W. H. and S, G, Ryan. (2000). Biases and lags in book value and their effects on the ability of the Book-to-Market ratio to predict book return on equity. Journal of Accounting Research, 38 (1), 127-148.

Budiono, G. S. (2005). Kualitas Laba: Studi pengaruh mekanisme corporate governance dan dampak manajemen laba dengan menggunakan analisis jalur. Makalah Simposium Nasional Akuntansi VII, Solo.

Burgstahler, D., and Dichev, I. (1997). Earning management to avoid earnings decreases and losses. Journal of Accounting and Economics, 24, 99-126.

Byungcherl, C. (2012). Analyst forecast, accounting conservatism on the related valuation implications. Accounting and Finance, 52, 311-341.

Chen, H., Tang, Q., Jiang, Y., and Lin, Z. (2010). The role of international financial reporting standards in accounting quality. Journal of International Financial
Management \& Accounting, Vol. 21 No. 32 , 220-278.

Cheng agnes, C. and Liu, C. (2007). The effect of accounting conservatism on value relevance of earnings from the perspective of investment in long-term operating assets. Working Paper, University of Houston.

Choi, T. H., and Pae, J. (2011). Business Ethics and Financial Reporting Quality: Evidence from Korea. Journal of Business Ethics 103 (3). 403-427.

Daske, H., Hail, L., Leuz, C., and Verdi, R. (2008). Mandatory IFRS reporting around the world: Early evidence on the economic consequences. Journal of Accounting Research, 46, 1085-1142.

Dewan Standar Akuntansi Keuangan. (2015). Pernyataan Standar Akuntansi Keuangan. Jakarta: Ikatan Akuntan Indonesia.

Dickhaut, J., S. Basu, K. McCabe, and G. Waymire. (2000). Neuroaccounting: Consilience between the biologically evolved brain and culturally evolved accounting principles. Accounting Horizons, 24, 221225.

Francis, J., Laford, R., Olsson, P., and Schipper, K. (2004). Cost of equity and earnings attributes. The Accounting Review, 79 (4), 967-1010.

Grambovas, C., Giner B., and Christododoulou, D. (2006). Earning conservatism: panel data evidence from the European Union and the United States. Abacus, 42(3-4), 354-378.

Ghozali, Imam. (2011). Aplikasi Analisis Multivariate dengan Program IBM SPSS 19. Badan Penerbit Universitas Diponegoro. 
Givoly, D., Hayn, C., and Natarajan, A. (2007). Measuring reporting conservatism. The Accounting Review 82 (1): 65-106.

Givoly, D. and Hayn, C. (2000). The changing time-series properties of earnings, cash flows, and accruals: Has financial reporting become more conservative? Journal of Accounting and Economics, 29 (3).

Gracia Lara, J., Gracia, O.,B., and and Penalva, F. (2009). Accounting conservatism and corporate governance. Review of Accounting Studies, 14(1), 161-201.

Gujarati, Damodar N. (2003). Basic Econometrics, fouth edition. Mc Graw Hill Inc. Singapore.

Hung, M., and Subramanyam, K. R., (2007). Financial statement effects of adopting international accounting standards: the case of Germany. Review of Accounting Studies 12, 623-657.

IASB. (2010). The Conceptual Framework of Financial Reporting. London: IFRS Foundation.

Insukindro. (1998). Sindrum $\mathrm{R}^{2}$ dalam analisis linear runtut waktu. Jurnal Ekonomi dan Bisnis, 13 (4).

Jeanjean, T., and Stolowy, H. (2008). Do accounting standards matter? An explanatory analysis of earnings management before and after IFRS adoption. Journal of Accounting and Public Policy, Vol. 27, 480-494.

Jensen, M., C. and Meckling, H. W. (1976). Theory of the firm: Manajerial behaviour, agency, and ownership structure. Journal of Financial Economics, Vol. 3.

Jonas, G. J. and Blanchet, J. (2000). Assesing quality of financial reporting. Accounting Horizons, 14(3): 353-363.
Karampinis, N., Hevas, D. (2011). Mandating IFRS in an unfavorable environment: The Greek experience. The International Journal of Accounting, 46, 304-332.

Khan, M. and R. Watts. (2009) Estimation and emperical properties of firm-year measure of accounting conservatism. Journal of Accounting and Economics, 48, 132-150.

Kothari, S., and Wasley, C. (1989). Measuring securities price perfomance in size-clustered samples. The Accounting Review, 64, 228249.

Krismiaji, A., Y., Aryani., and Suhardjanto, Djoko. (2013). Pengaruh adopsi International Financial Reporting Standard terhadap kualitas informasi akuntansi. Jurnal Akuntansi dan Manajemen (JAM), 24 (2), 6371.

Lang, M., Raedy, J., and Yetman, M. (2003). How representative are firms that are crosslisted in the United States? An analysis of accounting quality. J. Accounting Res, 41(2), 363-386.

Lara, J. and Mora, A. (2004). Balance sheet versus earning conservatism in Europe. European Accounting Review, 13 (2), 261292.

La Porta, R., Lopez-de-Silaes, F., Shleifer, A. and Vishny, R. (1998). Law and finance. Journal of Political Economy, 106(6), 11131155.

Leuz, C. (2010). Different approaches to a corpoarte reporting regulation: How jurisdictions differ and why. Accounting and Business Research, 40, 229-256.

Littleton, A. C. (1994). A genealogy for "cost market". The Accounting Review, 16, 161167. 
Lu, X. (2012). Information asymmtry and accounting conservatism under IFRS adoption. Working Paper, Faculty of Business, Brock University.

Lu, X. (2012). Information asymmtry and accounting conservatism under IFRS adoption. Working Paper, Faculty of Business, Brock University.

Martinez-Ferrero, J. (2014). Consequences of financial reporting quality on corporate perfomance. Evidence at the international level, Estudios de Economica 41 (1), 49-88.

Masca, E., and Neag, R.. (2014). Accounting conservatism in Europe: a literature review, Proceeding of the $2^{\text {nd }}$ International Scientific Conference IFRS: Global rule \& local use, Anglo-American University, Prague, Czech Republic, 113-127.

Mazars. (2006). IFRS 2005 European Survey. 152.

http://www.mazars.com/pdf/Enquete IFRS 2005 U.K.pdf. (accessed February, 2017)

Nobes, C. W., and Kvaal, E. (2010). International differences in IFRS policy choice. Accounting and Business Research, Forthcoming 2010.

Paananen, M., and Lin, H. (2009). The development of accounting quality of IAS and IFRS over time: the case of Germany. Journal of International Accounting Research, 8(1), 31-55.

Pascan, I., D. (2015). Measuring the effect of IFRS adoption on accounting quality: a review. Procedia Economics and Finance, 32, 580-587.

Penman, H. and Zhang, X. (2002). Accounting conservatism, the quality of earning, and stock returns. The Accounting Review, 77(2), 237-264.
Piot, Charles and Dumontier, Pascal (2010). IFRS consequences on accounting conservatism within Europe. JEL, 1 - 63.

Platikanova, P., and Perramon, J.. (2012). Economic consequences of the first-time IFRS introduction in Europe. Revista Espanola de Financiacion Y Contabilidad, XLI (156), 497-519.

PWC. (2010). https://pwcinform.pwc.com/inform2/show?ac tion=informContent \& id $=0846040811224011$ (accessed March, 2017).

Ratna., P., A. (2015). Kualitas informasi laba perusahaan manufaktur di Indonesia periode 2010-2013. Accounting and Business Information System Journal (ABIS), 14, 1-18.

Soderstrom, N., and Sun, K. (2007). IFRS adoption and accounting quality: A review. European Accounting Review, 16, 675-702.

Sterling, R. (1967). Conservatism: The fundamental principle of valuation in traditional accounting. Abacus, 3(2), 109132.

Van Tendeloo, B., and Vanstraelen, A. (2005). Earning management under German GAAP versus IFRS. European Accounting Review, 14(1), 155-180.

Watts, R (2003). Conservatism in accounting part I: Explanation and implications. Accounting Horizons, 17(3), 207-221.

Watts, R., L. and Zimmerman. (1986). Torwards a positive theory of the determination of accounting standars. The Accounting Review, $3,112-134$.

Zeghal, D., and Mhedhbi, K. (2006). An analysis of the factors affecting the adoption of international accounting standards by 
DOI: http://dx.doi.org/10.25181/esai.v12i2.1093

developing countries. The International Journal of Accounting, 41, 373-386.

Zeghal, D., Chtourou, S. M., Fourati, Y. M. (2012). The effect of mandatory adoption of IFRS on earning quality: Evidence from the European Union, Journal of International Accounting Research, 11 (2), 1-25.
Zeghal, D., and Lahmar, Z. (2016). The impact of IFRS adoption on accounting conservatism in the European Union. International Journal of Accounting and Financial Reporting, 6(1), 127-160. 